\title{
A China Case Study on Big Shareholders' Propping and Tunneling
}

\author{
Tangmei Yuan* \\ Department of Accounting, Linyi University, Shandong, China \\ yyytm@126.com \\ * The corresponding author
}

\begin{abstract}
Keywords: Corporate Governance; Big Shareholders; Controlled Supportive Behavior; Tunnel Behavior
\end{abstract}

\begin{abstract}
This paper, with the help of China Top Software Company case, have analyzed both the motivation and implement approaches of propping and tunneling actualized by big shareholders of China's listed companies. Propping and tunneling both are main shareholders' behavior of transferring benefits in different directions in order to maximize their own benefits, the propping aims at raise the performance targets of listed companies, and that tunneling, which usually does not have an effect on the current performance but which causes a long-term harm to company's value and minority shareholders' interests, aims to transfer actual resources to main shareholders.
\end{abstract}

\section{Introduction}

Although studies show that, some degree of ownership concentration is the effective way to reduce the agency cost between shareholders and managers (Shleifer and Vishny, 1997), But equity concentration lead to serious agency problem between big shareholders and small shareholders. La Porta et al. (1999) even conclude, “...the central agency problem in large corporations around the world is that of restricting expropriation of minority shareholders by controlling shareholders...".The controlling shareholder can extract private benefits through ranging from outright theft to selling assets or products at lower than market price to a firm in which she has higher stake, or buying at high price from the firm, damage the firm value, and violations small shareholders' interests. However, controlling shareholders can also use private resources to "prop up" the firm that is in trouble. That is, they temporarily transfer resources to the firm to boost the performance so that default or delisting is avoided.

Johnson et al.(2000) coin the term "tunneling" for the transfer of assets and profits out from the firms by controlling shareholders for their private benefits. Interestingly, controlling shareholders in certain circumstances use their own funds to prop up firms that are in financial distress, which Friedman et al. (2003) titles "propping".Thus, tunneling and propping are the two major purposes for controlling shareholders to engage connected transactions within their business group. They can both exist in the same company but during different time periods.

The question is when and how controlling shareholders are likely to choose tunneling or propping. What aspects of the company were caused impact by the two kinds of behaviors?

Although there have been some empirical research offered indirect evidence that the big shareholder occupy small shareholders interests from a different angle. But have few research on specific implementation process of big shareholders occupy behaviors, the research relevant supporting behaviors is less. So this paper attempts to use case study method to disclose big shareholders tunnel behaviors and support behaviors. And Top software provides a complete case.

\section{Literature Review}

Corporate governance has been a topic of research for decades. We herein review a few of recent studies regarding corporate governance. Li and Samsell (2009) suggest that economies vary in terms of their emphasis on formal rules versus informal relationships. In Anglo-American economies, the primary governance mechanism is the equity market (Saberwal \& Smith, 2008). In 
China, the primary governance mechanism is the state and informal networks (Shen \& Chen, 2009). Judge (2010) gives a complete review of corporate governance around the world.

Li (2010) examined tunneling by controlling shareholders in Chinese public companies, and concluded that tunneling is severe and that private controlling ownership significantly increases the severity of it. His research seems to support the conclusion by Shen and Chen (2009) that the primary governance mechanism in China is the state and informal networks. Recent study about ownership and corporate governance also includes Sueyoshi, Goto, and Omi (2010) research about Japanese firms. ${ }^{\mathrm{T}}$ heir conclusion is that stable shareholding is an important aspect of traditional Japanese corporate governance, although stable shareholding enhances operational performance only when the ratio of shares held by stable shareholders is more than $61.21 \%$.

However, Leuz, Nanda, and Wysocki (2003) finds that earnings management appears to be lower in economies with large stock markets, dispersed ownership, strong investor rights, and strong legal enforcement. This conclusion conflicts with research by Li (2010), Shen and Chen (2009), and Sueyoshi, Goto, and Omi (2010). These studies found that large/state shareholding was an important governance mechanism. Leuz et al. (2003) conclusions are based on data from 31 countries from 1990 to 1999. The countries include Asian countries such as Japan, Philippines, Indonesia, Korea, as well as the United States, United Kingdom, Belgium, etc. The dataset did not include China.

\section{The Characteristics of China's Capital Market Provide Convenience to Tunneling and Propping}

China is in the process of transferring from a central-controlled economy to a market economy, and a number of companies have been reformed to list on the stock exchange. The new emerging market offers a new trial site for examining tunneling and propping in terms of three characteristics:

(1) The weak legal institutions in place allow controlling shareholders to expropriate minority shareholders. Allen et al. (2005) show that China's law and institutions, including investor protection systems, corporate governance, and accounting standards are significantly less sophisticated than most of counterparts in Western - and even some developing countries. The World Economic Forum (2006) notes a lower ranking in terms of China's quality of the institutional environment, with poor results across all institutional indicators. Shleifer and Vishny (1997) suggest that when a low level of legal protection of minority shareholders exists, controlling entities may find it attractive to divert resources from firms despite their large cash flow shareholdings.

(2) An equity segment structure provides the incentive for controlling shareholders to expropriate minority shareholders. In China, the majority of outstanding shares owned by controlling owners are not floatable on the two stock exchanges. Although the non-floatable shares are transferable between non-floatable share owners on a negotiation basis (but are still non-floatable after the transfer), the transferable price is based on the face value of the firm, which is, on average, 20 percent of the price of floatable shares (Chen and Xiong, 2002). Given the huge share price discount, controlling shareholders are virtually isolated from the wealth effect derived from the fluctuation of the share prices determined by the market. However, conversely, the controlling shareholders may have strong incentives for expropriation, despite their large shareholding. The so-called "aligning effect" of large shareholders in addressing the agency problem (such as the active monitoring of management) does not exist in Chinese listed firms because of the equity segment structures.

(3) The listing quota and carve-out (or spin-off) listing processes impair the independence of listed firms and incur related party transactions (RPTs). In China, because of the quota limit, many listed firms are actually spin-offs from parent companies. Normally, the most profitable or productive assets are carved out into the listed firm. The original company will retain the low profitable assets and become the parent or holding company after the carve-out and part listing. The contributions made by the controlling shareholders give them extra incentive to take back by tunneling. 


\section{Case Discussion on Top Software}

Company Profile. The full name of Top Software is "Sichuan Top Changzheng Software Co Ltd" (000583), it major made Computer / IT hardware \& software. its precursor is Long March Machine Tool Co., LTD. Company initial public offering on November 1, 1995, in ShenZhen Stock Exchange, (when initial public offering, its shortened form "Sichuan Long March"), the total stock is 62.9459 million shares, tradable stock are 25 million shares among them. In 1998, Sichuan Top Technology Development(Top Development) buy the old first big shareholders all stocks, 42.6243 million shares, for $48.37 \%$ of the total equity, became the new first major shareholders. And so Top Development realize listed by shell. After that, Top Software stock became optimal performance software shares in market, share price rise sharply with restructuring and performance goes up, from $5 \mathrm{CNY}$ to $48 \mathrm{CNY}$ per share. Then Top Software succeed to implement the secondary offerings with the high price of $\$ 28$ per share in 2000, raise funds of 950 million CNY in stock market.

But Top Software the image of growth blue chip stocks did not last longer. In 2002, company's performance began to drop and exposed the big shareholders occupy the company huge amount of money, offers a lot guarantee for affiliated parties, then in 2003, the company began to appear huge losses(details see Table 1). lawsuits constantly for the guarantee and assume joint liability, main production assets frozen by the court, the company situation is very difficult.

Table 1 Top Software performance each year

\begin{tabular}{l|r|r|r|r|r|r|r|l}
\hline \multicolumn{1}{c|}{$\begin{array}{c}\text { Performance } \\
\text { index }\end{array}$} & 1997 & 1998 & 1999 & 2000 & 2001 & 2002 & 2003 & 2004 \\
\hline $\begin{array}{l}\text { Main business } \\
\text { income (ten } \\
\text { thousand CNY) }\end{array}$ & 6643 & 22076 & 27422 & 50827 & 71100 & 67746 & 21284 & 7742 \\
\hline $\begin{array}{l}\text { Net income (ten } \\
\text { thousand CNY) }\end{array}$ & -2010 & 2936 & 5751 & 8729 & 8852 & 5098 & -38890 & -136671 \\
\hline EPSWA(CNY) & -0.228 & 0.333 & 0.652 & 0.72 & 0.726 & 0.22 & -1.679 & -5.9 \\
\hline
\end{tabular}

Data source: Top software regularly report.

\section{Big Shareholder Support Behaviors-Propping}

When Top Development buy equity of Sichuan Long March, Sichuan Long March the total equity for 88.1243 million shares, circulation stock is only 35 million shares. Sichuan Long March main business is machine tools, at the time of mechanical industry under the background of recession, Sichuan Long March`s performance worsened, and cannot get equity refinancing qualification since listing in the 1995. Top Development buy the tradable share and become the big shareholder, do look at the listed company's shell resources, and the value of shell resources is reflected financing Capabilities in the securities market. When Sichuan Long March itself operational performance beyond reach of refinancing standard, the big shareholder through the support behavior improve the company performance and regain refinancing qualification. In the choice of equity financing way, Top Software chose secondary offerings.

Top Software implement secondary offerings in May 2000, the performance of reaching refinancing standard mainly from 1998 to 1999. In 1998, by implement restructuring, Top Software net income rose from last year's- 20.1 million jumped to $\$ 29.36$ million CNY. According to Top Software public information, can found that the big shareholder through the following several main methods for support behavior and rapid promotion company performance.

(1)Big shareholder bring it controlled strong profitability business into Top Software, promote quickly report performance. Top software rapid growth in profits almost entirely come from the big shareholders controlled business, computer software and hardware (details see Table 2). 
Table 2 Top Software Business Constitute

\begin{tabular}{l|l|l|l|l|l|l}
\hline \multirow{2}{*}{ Business } & \multicolumn{2}{c|}{1998} & \multicolumn{2}{c}{1999} & \multicolumn{2}{c}{2000} \\
\cline { 2 - 8 } & $\begin{array}{l}\text { Main } \\
\text { Revenu } \\
\text { e }\end{array}$ & $\begin{array}{l}\text { Main } \\
\text { gross } \\
\text { profit }\end{array}$ & $\begin{array}{l}\text { Main } \\
\text { Revenu } \\
\text { e }\end{array}$ & $\begin{array}{l}\text { Main } \\
\text { gross } \\
\text { profit }\end{array}$ & $\begin{array}{l}\text { Sales } \\
\text { Revenue }\end{array}$ & $\begin{array}{l}\text { Main } \\
\text { profit }\end{array}$ \\
\hline $\begin{array}{l}\text { Network integration and } \\
\text { computer software }\end{array}$ & 18445 & 8220 & 24880 & 13311 & 23715 & 14848 \\
\hline $\begin{array}{l}\text { Machine tools and } \\
\text { accessories }\end{array}$ & 3631 & 20 & 2542 & -140 & 3282 & 147 \\
\hline $\begin{array}{l}\text { PC accessories and trade } \\
\text { income }\end{array}$ & & & & & 27828 & 861 \\
\hline $\begin{array}{l}\text { The company offset each } \\
\text { other between industries }\end{array}$ & 22076 & 8240 & 27422 & 13171 & 50827 & 15856 \\
\hline \multicolumn{1}{c|}{ Total } & & & & 3998 & \\
\hline
\end{tabular}

Data source: Top software regularly report and the temporary public announcement, public material.

In addition to Top Software itself business transformation, carry out IT related business. Big shareholder then used equity transfer method, sell the higher profits subsidiary to top software, fit into the Top Software consolidated financial statements range. These purchases subsidiary made contribution to Top Software profits in a certain period. Top Development sale it controlled "Chengdu Top Science and Technology Co., LTD." 53.85\% equity to Sichuan Long March, included in the scope of the consolidated financial statement in January 1998, as the first step Top Development to restructuring the Sichuan Long March. The company made profit is the $22.84 \%, 39.04 \%, 26.85 \%$ of Top Software total net profit (details see Table 3).

Table 3 Chengdu Top Science Technology Co., LTD profit contribution to Top Software

\begin{tabular}{|c|c|c|c|c|}
\hline year & $\begin{array}{l}\text { Top } \\
\text { Science-Technology } \\
\text { net profit }\end{array}$ & $\begin{array}{l}\text { contribution to } \\
\text { Top Software net } \\
\text { profit }\end{array}$ & $\begin{array}{l}\text { Top Software } \\
\text { net profit }\end{array}$ & proportion(\%) \\
\hline 1998 & 1245 & 670 & 2936 & 22.84 \\
\hline 1999 & 4169 & 2245 & 5751 & 39.04 \\
\hline 2000 & 4353 & 2344 & 8729 & 26.85 \\
\hline
\end{tabular}

Data source: Top software, Chengdu Top Science Technology Co., LTD regularly report and the temporary public announcement, public material.

Another affair, Top Software bought Top Electronic Information Company shares from affiliated parties, buying cost is only 1.35 million yuan in September 1999, but the company created the net profit 4.35 million yuan in 2000. Top Software often bought company stock and equity or sell shares from affiliated parties, these deals is hard to let people consider have not the motivation of earnings management.

(2)Top Software sell idle asset to affiliated parties get income. Idle asset can't create income for the company, but need extract depreciation offset company profits per issue. Top Software sold idle fixed assets to affiliated parties, can get current profits through higher pricing, because both the seller and the buyer all are controlled by large stockholder. At the same time need not extract depreciation of the assets in the future each periods. Top Software sell part of the lower utilization rate equipment and workshop to affiliated parties Zigong high-tech Co., LTD(belong to Sichuan top group) on July 29, 1998. This batch of assets book original value is 123.14 million yuan, net worth $\$ 69.77$ million, both parties trading price is $\$ 78.54$ million, Top software confirm income 8.35 million yuan in this deal. At the same time, because of the asset disposal, Top Software can reduce the depreciation 4 million yuan each year, amount to the pre-tax profit increase. 
(3)Top Software gains profit through short-term investment or financing to affiliated parties. According to the Top Software announcement, on September 1, 1998, Top Software invest 85.14 million yuan to Sichuan Top Group, Zigong high-tech Co., LTD, to solve computer 2000 problems, the investment period is 10 months, two sides identified investment return is $20 \%$, Top Software obtained income 14.19 million yuan from this investment.

\section{Shareholders' Tunneling: Shift Company Resources}

Big shareholders of a listed company provide support, the purpose is make the listed company to get more resources, and the final purpose of big shareholders is still the maximization of self-interest. After Top Software implement refinancing, trying to maintain its achievement, at the same time, big shareholders have realized resources transfer through all kinds of covert channel. Tunnel behavior mainly through the related party transaction realized. In the case of the Top Software, big shareholder transfer benefit from listed company mainly through the following ways.

(1)By related transaction, A great quantity money and interest transfer to the affiliated parties when using the financing money. Top Software open information display: Its implemented Seasoned Equity Offering in May 2000, and raise capital of 954 million yuan. The company promised investment project includes six aspects in the company Secondary offerings document: software export base construction, based on network software support platform and integration framework application, the enterprise information common platform and execution system construction, information appliance product embedded operating system development and industrialization, open intelligent nc system development and industrialization, network distributed environment numerical control machine tool technology improvement. But the last two projects have made changes in the actual investment, their money invest to buy "Chengdu education investment management limited company" shares. According to the actual investment content and mode, raise funds major invest to "Buy or entrust development intangible assets", "Construction and purchase fixed assets" , "purchase or set up subsidiaries". Top software raise funds invest statistics details see Table 4.

Table 4 Investment orientation of Top Software raise funds from Seasoned Equity Offerings

\begin{tabular}{l|c|c}
\hline Raise funds investment orientation & Investment amount & $\begin{array}{c}\text { Among them: related } \\
\text { party transactions }\end{array}$ \\
\hline Commissioned development software & 12708 & 12708 \\
\hline Buy intangible assets (software & 5709 & 5709 \\
\hline $\begin{array}{l}\text { Construction and purchase of fixed } \\
\text { assets }\end{array}$ & 16742 & 10359 \\
\hline Stock Purchase & 27000 & 27000 \\
\hline Set up subsidiaries & 10450 & \\
\hline Added liquidity and project funds & 22832 & 55775 \\
\hline Total & 95441 & \\
\hline
\end{tabular}

Data source: Top software regularly report and the temporary public announcement.

Table 4 shows that Top Software raise funds invest projects are almost related party transactions, in addition to set up subsidiaries and added liquidity outside, a total of $\$ 557.75$ million fund to the affiliated parties. Of course, we can't affirm big shareholder must be encroached on the interests of the company only because these deals are related transactions, but can find support this judgment's reasons thorough analysis these affiliate transaction.

First, from the intuitive judgment, it doesn't fit into general Top Software as a software as its main business enterprise, actually huge input for the development software entrusted affiliated parties or directly purchase software from affiliated parties. Secondly, Top Software purchased these assets from affiliated parties did not bring to the company expected earnings, annual report 2002 shows, the investment of raise funds gain income is only 33.74 million yuan. In addition, 
intangible assets that Top Software purchased from affiliated parties extract depreciation large proportion, show that the real value of the purchased assets is doubtful.

Based on the above analysis, we put this kind of related transaction as one way of big shareholders tunnel behaviors.

(2) Top Software provide bank loans guarantee for the affiliates

According to Top Software penalty adjudicated by the China securities regulatory commission on September 23, 2005: till June 30, 2004, Top Software provide guarantee for 17 affiliated companies, totally 101 bank loans, amount of 2.14568 billion yuan. Due to the affiliated did not return bank loans on time, Top Software contingent liability of huge guarantee were gradually becoming the heavy actual debt burden, Top Software 2004 annual reports, because lenders prosecution, the court has judgment that the company shall bear joint liability is 1.48372 billion yuan. The company has accumulated to guarantee loss 900.42 million yuan according to court at the end of 2004.

(3) Big shareholders occupy directly Top Software`s large amounts of cash.

Top Software transfer funds to associated company for no business background, Big shareholder or any other associated party takes up Top Software company funds balance is 747.58 million yuan by December 31, 2004. Top Software plan carry the provision 352.54 million yuan for the affiliated parties occupied funds in 2004.

In short, big shareholder's tunnel behaviors have a common characteristics is not involved in the profits and losses course of the Top Software, do not affect company profits and losses in the current period. At the same time, on a large amount of cash outflows company, the company's assets subject also increased (although these asset has water). And the guarantee cannot reflect in accounting statement, do not affect the company performance before undertake joint and several liability. Of course, in the long term, these deals caused extensive damage to company, existing moisture sets shall be drawing depreciation reserves, and the guarantee shall be bear joint responsibility reimbursement, eventually leading to the company's huge losses, share prices collapse, small shareholders suffer great losses.

\section{Conclusion}

According to above analysis, Propping and tunneling both are main shareholders' behavior of transferring benefits in different directions in order to maximize their own benefits, that propping aims at raisin the performance targets of listed companies, and that tunneling, which usually does not have an effect on the current performance but which causes a long-term harm to company's value and minority shareholders' interests, aims to transfer actual resources to main shareholders.

\section{Acknowledgements}

Project funding: Shandong social science planning project(16CKJJ21), phased research results.

\section{References}

[1] Shleifer A. and Vishny R., 1997, “A Survey of Corpo-rate Governance”, Journal of Finance, 52(2), pp.737 783.

[2] La Porta R. Lopez- de- Silanes F., Shleifer A., 1999, “Corporate Ownership Around the World”, Journal of Finance, 54(2), pp.471 517.

[3] Johnson S., LaPorta R., Lopez- de- Silanes F., Shleifer A., 2000, "Tunneling", American Economic Review, 90(2), pp.22 27.

[4] Friedman E., Johnson S., Mitton T., 2003, "Propping and Tunneling", Journal of Comparative Economics, 31(4), pp.732 750.

[5] Li, S., \& Samsell, D. (2009). Why some countries trade more than others: The effect of governance environment on trade flows. Coporate Governance: An International Review, 17, $47-61$. 
[6] Saberwal, S., \& Smith, S. (2008). Concentrated shareholders as substitutes for outside analysts. Corporate Governance: An International Review, 16, 562-577.

[7] Shen, W., \& Chen, Lin (2009). Firm profitability, state ownership, and top management turnover at the listed firms in China: A behavioral perspective. Corporate Governance: An International Review, 17, 443-456.

[8] Judge, William (2010). Corporate Governance Mechanisms throughout the world. Corporate Governance: An International Review, 18(3), 159-160.

[9] Li, Guoping (2010). The pervasiveness and severity of tunneling by controlling shareholders in China. China Economic Review, 21, 310-323.

[10] Leuz, Christian, Nanda, Dhananjay, \& Wysocki, Peter D. (2003). Earnings management and investor protection: an international comparison. Journal of Financial Economics, 69, 505-527.

[11] Sueyoshi, Toshiyuki, Goto, Mika, \& Omi, Yusuke (2010). Corporate governance and firm performance: Evidence from Japanese manufacturing industries

[12] Atanasov V.A., 2005, "How Much Value can Block-holders Tunnel? Evidence from the Bulgarian Mass Privatization Auctions", Journal of Financial Economics, 76(4), pp.191 234. 